\title{
Nodal marginal zone B-cell lymphoma
}

INSERM

\section{Source}

INSERM. (1999). Orphanet: an online rare disease and orphan drug data base. Nodal marginal zone B-cell lymphoma. ORPHA:86867

Nodal marginal zone B-cell lymphoma is a rare, indolent B-cell non-Hodgkin lymphoma, characterized by abnormal clonal proliferation of mature B-lymphocytes with involvement of the lymph nodes, sometimes the bone marrow, and rarely the blood. Clinically it presents with disseminated peripheral, abdominal and/or thoracic lymphadenopathy. Cytopenia and bulky tumors (greater than $5 \mathrm{~cm}$ ) are rare. Association with Hepatitis C virus and chronic inflammation has been reported. 